\title{
If the world fails to protect the economy, COVID-19 will damage health not just now but also in the future
}

\author{
Previous crises have shown how an economic crash has dire consequences for public health. But in the COVID-19 \\ pandemic, the world is entering uncharted territory. The world's leaders must prepare to preserve health.
}

\section{Martin McKee and David Stuckler}

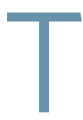
he COVID-19 pandemic is, first and foremost, a health crisis. However, it is rapidly becoming an economic one too. This is not, of course, the first global economic crisis. However, this time it is different.

The 20th century experienced the 1929 Wall Street crash and the 1973 oil-price shock, as well as numerous regional crises in East Asia, the former Soviet Union, and Latin America. The early years of the 21st century saw the global financial crisis that started in 2007. Each of these crises has been studied in detail and, while economists and politicians might disagree about how to respond, often reflective of their ideological perspective, there are at least a range of measures that they can select from.

Those studying economic crises have long drawn on biological analogies, drawing especially on the idea of 'contagion', used initially to explain the spread of banking failures in the $1920 \mathrm{~s}^{2}$. John Maynard Keynes, drawing on earlier philosophers, spoke of confidence in the market as "animal spirits."

However, those concepts were being applied to the actions of people, actions that could be influenced by statements and actions of politicians, for better or worse. They still have some value. A late-night tweet by US President Trump can send the financial markets into freefall ${ }^{4}$. However, such concepts do not influence a viruswhich is not following the US president on Twitter.

Just over a decade ago, governments undertook large-scale experiments on their populations. Each decided whether or not to adopt austerity measures in the aftermath of the global financial crisis ${ }^{5}$. The consequence was that many of their citizens who had previously felt secure found themselves leading lives that were extremely precarious. Increasingly, they found themselves living from month to month, facing insecurity of employment, income, housing, and even food ${ }^{6}$.
Countries such as Greece, Italy, Spain, and, after 2010, the UK that had chosen to implement austerity measures or had such measures imposed on them, or that suffered loss of traditional industries, experienced worsening health, which typically took the form of what would be termed 'diseases of despair", such as alcohol- and drugrelated deaths and suicides. An estimated 10,000 additional suicides occurred in the aftermath of the 2007 global financial crisis ${ }^{8}$. In the UK, where food banks were virtually a foreign concept, there was a mass rise in people seeking emergency food support, particularly in those areas hit by austerity? In several countries, especially the USA and UK, the long-term improvement in life expectancy was arrested ${ }^{10,11}$.

This had political consequences too. Many of those living in areas most affected abandoned long-standing allegiances to vote for populist causes, which led to policies that would harm them further ${ }^{12,13}$.

However, this did not happen everywhere. Some governments, such as those of Germany, the Netherlands, and, before the 2010 general election, the UK, rejected austerity and sought to stimulate the economy, often accompanied by measures to protect the most vulnerable, such as those that were well established in Scandinavian countries. Thus, while in many European countries, the rise in suicides rose in parallel to job losses, in some, the link was broken. These were the countries that sought to give their people hope-for example, with policies to ease them back into work should they lose their jobs or to protect them from becoming homeless ${ }^{14}$.

\section{An economic crisis will follow this outbreak}

Today, politicians must make difficult choices, although with imperfect information. Measures needed to contain the virus, including self-isolation by workers and consumers, closure of factories and shops, and bans on sports and entertainment activities, all take their toll. Politicians are turning to public-health experts to help them in this crisis, exemplified by the appearance of Anthony Fauci at the side of US President Trump, or UK Prime Minister Boris Johnson's being flanked by the UK Chief Medical Officer and Chief Scientific Advisor. In the UK at least, with a government whose ministers only recently proclaimed that the British people "have had enough of experts"15, this is quite a change.

The problem is that the advice that these experts are giving poses an immediate threat to the economy. This matters. Economic decline itself has an adverse effect on health. A reduction in economic activity reduces the circulation of money and, with it, tax revenues. This reduces the finances available for the public-health countermeasures needed to control the pandemic. It also hits individuals and families, who may see their income plummet catastrophically. Once they have depleted their financial reserves, companies close, with consequences for their owners, employees, and suppliers.

In China, where COVID-19 first struck, industrial production fell by about $13.5 \%$, and seasonally adjusted retail sales are down $21 \%$. Some sectors have almost completely collapsed. Car sales fell $92 \%$, and restaurants sales dropped by $\sim 95 \%$. Goldman Sachs has predicted that the US economy could shrink by $24 \%$ in the second quarter of 2020, more than twice as much as any decline ever recorded ${ }^{16}$.

It is important to note that an outbreak that requires social distancing and quarantine for control is likely to develop very differently in a setting in which there is a workforce with access to free healthcare and income protection than in one in which much employment is casual and people must choose whether to go to work when ill or to starve.

The increasingly integrated global economy increases the fragility of this 
situation. A manufacturer of ventilators in Sheffield, Detroit, or Dusseldorf may depend on specialized supplies from Shanghai, Manila, and Kuala Lumpur. If any one of these is unable to deliver their products, the entire process may collapse. Also, as with any complex system, what happens can depend critically on starting conditions.

Assessing the scale of the economic damage is made more difficult because no one knows how long the restrictions on activities will last. The economy acts as a complex adaptive system. Thus, it includes a degree of resilience, bouncing back from a shock. However, at some point, the compensatory mechanisms break down. When a company closes, it may never re-open. The skilled labor on which it depends may be lost. However, there is a lot of uncertainty in this outbreak. Models suggest that the pandemic could last either a few months or up to a year in many countries. There could be either one wave or a series of waves of the pandemic ${ }^{17}$.

Even if the scale and nature of the pandemic and associated economic downturn are difficult to quantify, there is little doubt that there is a real risk of a vicious downward spiral of illness and impoverishment. Research and development that might have been undertaken may have been delayed. Education that might have been completed may have been interrupted. Investments that might have been made may have been put on hold. And many people will have had their lives changed forever, often for the worse.

\section{How to protect the economy?}

What can be learned from this experience? How can a return of the worst consequences of the global financial crisis be avoided? Measures commonly used by governments and central banks, such as lowering interest rates or implementing fiscal stimuli, have only limited effect. At most, they can mitigate the effects. Here we propose three sets of measures that, we believe, can help societies recover once this pandemic is over.

Save lives. This is the first and most obvious priority. The spread of the causative virus must be contained and the deaths associated with it must be reduced, as quickly as possible. The scale of the measures taken to achieve such a containment will influence the stage of the pandemic and the capacity to intervene, in particular whether healthcare workers and laboratory facilities are available to respond to the increased workload. Now is not the time for penny-pinching-finance ministries and donor agencies must recognize that this will require additional funding, obtained from reserves or by borrowing. Crucially, those designing these public-health countermeasures must recognize that there will be direct and indirect health effects, affecting in particular those living alone, those who are elderly or those who have mental illness, or those who are homeless or in institutions such as care homes, prisons, and migrant detention centers. Importantly, a new study of the 1918 influenza pandemic finds that in the 43 US cities studied, those that imposed restrictions on social interactions earlier and retained them longer experienced a stronger subsequent recovery ${ }^{18}$. Hence, the authors reject the idea of a trade-off between strict publichealth measures and economic damage.

Protect financial risk, now. Because there is a collapse in demand within the economy, the responsibility to protect financial risk must fall on the governments. Just as governments accept that they must find additional money in time of war, they must rally against this common enemy-a microorganism, rather than a foreign power-because the threat to their population is no less. Politicians in many countries have responded to the challenge, often throwing long-established fiscal rules out of the window ${ }^{19}$. The US $\$ 2$ trillion package enacted in the USA is unprecedented, but many European countries, including the UK, France, and Denmark, have stepped in to pay a large proportion of the wages of those who are at risk of losing their jobs. This is critical to stave off permanent damage and prevent a recession from escalating into a full-blown depression. The concerns about high levels of government debt that were used to justify austerity a decade ago ${ }^{20}$ have been set aside.

Prepare for recovery. This means securing the future of companies, particularly of the small and medium enterprises that play such an important role in the economy, so that they are ready to meet the demand that will someday return. In preindustrial times, economies simply needed a large supply of labor.

The modern knowledge economy, in both manufacturing and services, depends on a highly skilled and often specialized workforce. Once those skills are lost-for example, because those who have reached middle age, who are unlikely to return to the workforce, are forced into redundancythen recovery can be almost impossible.

This requires measures to provide companies with financial lifelines, such as the interest-free loans being provided by some governments, as well as those that reduce the costs falling upon businesses. Examples of this include deferment of tax payments, interest on loans, and utility bills, and financial support to enable employees to be furloughed ${ }^{21}$.

This protection must also take heed of those who seek to benefit from a crisis. Throughout history, crises have encouraged the emergence of profiteers ${ }^{22}$. In this outbreak, there have already been many accounts of substantial markups on products such as hand sanitizers and protective equipment. Others exploiting a crisis include lenders who ramp up interest rates. These phenomena point to the importance of government controls on prices. Another group that stands to benefit is other speculators in the financial markets. Some people have already made enormous profits from this pandemic, which has in some cases led to questions about insider knowledge. However, it is important to remember that their profits are someone else's losses, and it is often the pension funds of some of the poorest in society that are hit hardest.

Then there are those who will appear in the aftermath of the pandemic, just like the carpetbaggers at the end of the US Civil War, taking advantage of those who are desperate for money and have no option but to sell their businesses. A leading private-equity firm has already explained how "During and post this crisis, [private-equity] firms will be presented with unique opportunities to invest," taking advantage of companies unable to pay their debts ${ }^{23}$.

Finally, as described by Naomi Klein in her book The Shock Doctrine ${ }^{24}$, there is a danger that politicians, often linked to powerful vested interests, will use a crisis to undermine labor, health, and environmental protections, with long-term consequences for health. This seems to be happening already in the USA, with important environmental regulations being repealed ${ }^{25}$.

\section{Learning now from mistakes}

Although there is an immediate need to respond to the ongoing crisis, the political and economic context that led the world here must not be ignored. One reason the COVID-19 pandemic, will have, and has already had, such a serious economic impact is that countries have organized their societies in ways that render them extremely vulnerable. They have created a reward structure that benefits an increasingly small and select elite while devaluing those on whom they depend to keep them safe ${ }^{26}$.

For four decades, many countries have weakened organized labor and have created an ever-larger workforce on insecure contracts, which has left many of their 
citizens with no idea of how much they will earn from week to week. In some countries, such as the USA, many people have access to only the most basic of essentials, including healthcare. It is important to acknowledge that while those with secure incomes can afford to self-isolate if they become ill, those on 'zero-hour' contracts must choose between eating and protecting others. As a consequence, even the wealthiest societies are only as strong as their weakest members. It is therefore perhaps unsurprising that some politicians, who would not naturally see their interests aligned with the worst off, are recognizing this interdependency ${ }^{19}$. Those doing jobs that only a few months ago would have led to rejection of their visa requests as those performing unskilled labor are now seen as essential.

It is impossible to predict the future. However, the realization that anyone can be infected with the coronavirus that causes COVID-19, whether the UK Prime Minister or an heir to the throne, is a reminder of the shared vulnerability of humans. This parallels the period after World War II, when a generation had seen that anyone could fall victim to a falling bomb. Across Western Europe, those who had survived the war created welfare states that would not seek complete equality but instead would ensure that whatever befell them, they would be safe. When making their political choices, they behaved as if they were behind what the philosopher John Rawls described as a veil of ignorance, with no knowledge of their position on the other side ${ }^{27}$. As political economist Alberto Alesina and others have argued, this was never the case in the USA, where you would always know whether you were black or white $\mathrm{e}^{28}$. In a pandemic, just as during a world war, everyone in its path, rich or poor, is susceptible, and no one can feel secure. This should offer some hope for a fairer, safer, and more secure society.

However, caution is required. Some politicians have sought to weaponize the pandemic, portraying the threat as a hoax or an exaggeration by those seeking to attack them ${ }^{29}$. This seems to have been effective. Survey data from each state of the USA, disaggregated by political allegiance, shows a clear gap between Democrats and Republicans in the extent to which COVID-19 is seen as a threat ${ }^{30}$. Even more worrisome is how epidemics often cause people to look to others they can blame. The Black Death in Europe was accompanied by widespread pogroms, with Jews being accused of poisoning wells ${ }^{31}$. US President Trump repeatedly refers to the 'Chinese virus', and UK politicians, if not quite so blatantly, have also pointed the finger at China ${ }^{32}$. However, in a sign of hope, there is also evidence that the large gap between Republican and Democrat voting areas in online searches for 'hand sanitizer' has narrowed.

The world is at a crossroads. The COVID-19 pandemic could encourage people to realize that they all depend on each other on this small planet and, whether it is global heating, inequality, or environmental degradation, will either swim or sink together. On the other hand, populist politicians and the vested interests that support them, especially in the mass media, could use this crisis to sow divisions, creating cleavages between the young and old, rich and poor, sick and healthy, ethnic minorities and population majorities, immigrants and domestic groups, weakening the collective bonds and support for essential public goods ${ }^{33}$.

Here it may be useful to recall how, before the World War I, women in the workplace were grossly undervalued. Although they had to fight for it, the contribution they made was eventually recognized in the extension of franchise in a number of countries. Similarly, the wake of the Great Depression, during which both the rich and poor lost their bets, led to the New Deal, including Social Security, which founded the origins of US social safety nets and pensions.

Could it be that society will at last recognize the value contributed by those whose work is so often invisible? The COVID-19 pandemic could be a turning point, restoring faith in science and bringing people together. However, this will happen only if the voices of scientists and healthcare professionals are heard. Politics and health have always been inextricably linked and always will be $\mathrm{b}^{34}$.

\section{Martin McKee (D) ${ }^{1 凶}$ and David Stuckler ${ }^{2 凶}$ ${ }^{1}$ Centre for Global Chronic Conditions, London School of Hygiene and Tropical Medicine, London, UK. ${ }^{2}$ Dondena Centre for Research on Social Dynamics and Public Policy, Bocconi University, Milan, Italy.

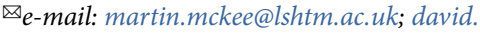 stuckler@unibocconi.it}

Published online: 9 April 2020

https://doi.org/10.1038/s41591-020-0863-y

References

1. Peckham, R. Econ. Soc. 42, 226-248 (2013).

2. Calomiris, C.W. \& Mason, J.R. Contagion and Bank Failures During The Great Depression: The June 1932 Chicago Banking Panic. Report No. 0898-2937 (National Bureau of Economic Research, 1994).

3. Keynes, J.M. The General Theory of Employment, Interest, and Money (Palgrave Macmillan, 2018).

4. Franck, T. CNBC https://www.cnbc.com/2019/09/03/on-dayswhen-president-trump-tweets-a-lot-the-stock-market-fallsinvestment-bank-finds.html (2019).

5. Reeves, A., McKee, M., Basu, S. \& Stuckler, D. Health Policy 115, 1-8 (2014).

6. McKee, M., Reeves, A., Clair, A. \& Stuckler, D. Arch. Public Health 75, 13 (2017).

7. Case, A. \& Deaton, A. Brookings Pap. Econ. Act 2017, 397-476 (2017).

8. Reeves, A., McKee, M. \& Stuckler, D. Br. J. Psychiatry 205, 246-247 (2014).

9. Loopstra, R. et al. Br. Med. J. 350, h1775 (2015).

10. Ho, J. Y. \& Hendi, A. S. Br. Med. J. 362, k2562 (2018).

11. Hiam, L., Harrison, D., McKee, M. \& Dorling, D. J. Epidemiol. Community Health 72, 404-408 (2018).

12. Koltai, J., Varchetta, F. M., McKee, M. \& Stuckler, D. Am. J. Public Health 110, 401-406 (2020).

13. Bor, J. Am. J. Public Health 107, 1560-1562 (2017).

14. Stuckler, D., Basu, S., Suhrcke, M., Coutts, A. \& McKee, M. Lancet 374, 315-323 (2009).

15. Mance, H. Financial Times https://www.ft.com/content/3be4973429cb-11e6-83e4-abc22d5d108c (2016).

16. Reinicke, C. Markets Insider https://markets.businessinsider. com/news/stocks/us-gdp-drop-record-2q-amid-coronavirusrecession-goldman-sachs-2020-3-1029018308 (2020).

17. Enserink, M. \& Kupferschmidt, K. Science 367, 1414-1415 (2020).

18. Correia, S., Luck, S. \& Verner, E. SSRN http://dx.doi.org/10.2139/ ssrn.3561560 (2020).

19. Rawnsley, A. The Guardian https://www.theguardian.com/ commentisfree/2020/mar/22/coronavirus-crisis-ignites-bonfireof-conservative-orthodoxies (2020).

20. Cassidy, J. The New Yorker https://www.newyorker.com/news/ john-cassidy/the-reinhart-and-rogoff-controversy-a-summing-up (2013).

21. Guerrieri, V., Lorenzoni, G., Straub, L. \& Werning, I. https://economics.mit.edu/files/19351 (2020).

22. Nordstrom, C. Shadows Of War: Violence, Power, and International Profiteering in the Twenty-First Century Vol. 10 (University of California Press, 2004).

23. Dayen, D. The American Prospect https://prospect.org/ coronavirus/unsanitized-private-equity-licks-its-chops/ (2020).

24. Klein, N. The Shock Doctrine (Penguin Books, 2007).

25. Kaufman, A.C. \& D’Angelo, C. HuffPost https://www. huffingtonpost.co.uk/entry/trump-epa-coronavirus-environmentderegulation n $\_5$ e7e3227c5b6cb9dc19f6728?ri18n=true (2020).

26. Piketty, T. Capital in the 21st Century (Harvard University Press, 2014).w

27. Rawls, J. A Theory of Justice (Harvard University Press, 2009).

28. Alesina, A., Glaeser, E. \& Glaeser, E.L. Fighting Poverty in the US and Europe: $a$ World of Difference (Oxford University Press, 2004).

29. Phillips, T. The Guardian https://www.theguardian.com/ world/2020/mar/23/brazils-jair-bolsonaro-says-coronaviruscrisis-is-a-media-trick (2020).

30. Badger, E. \& Quealy, K. The New York Times https://www.nytimes. com/interactive/2020/03/21/upshot/coronavirus-public-opinion. html (2020).

31. Lupovitch, H.N. Jews and Judaism in World History (Routledge, 2009).

32. Proctor, K. The Guardian https://www.theguardian.com/ politics/2020/mar/29/michael-gove-appears-to-blame-chinaover-lack-of-uk-coronavirus-testing (2020).

33. Hobbes, T. Leviathan (Penguin, 1968).

34. Virchow, R. C. Am. J. Public Health 96, 2102-2105 (2006).

Competing interests

The authors declare no competing interests 